\title{
The Effect of Learning Strategy Training and Group Cohesiveness on Effectiveness of Decision Making
}

\author{
Harti Supriatin ${ }^{1}$, Suparno Eko Widodo ${ }^{2}$, Rita Retnowati ${ }^{3}$ \\ ${ }^{1,2,3}$ Post Graduate Program, Universitas Pakuan Bogor, Indonesia \\ *Corresponding Author: Harti Supriatin, Post Graduate Program, Universitas Pakuan Bogor, \\ Indonesia
}

\begin{abstract}
The purpose of the research is to find out the influence of training method and group cohesiveness to the effectiveness of decision making. Learning strategy training and group cohesiveness serve as independent variable while decision-making effectiveness variable is the dependent variable. The sample of the research is ninety teachers chosen randomly from cluster sampling of 120 teachers from 18 private accredited A senior high schools in Bekasi city. Hypothesis testing was conducted on the level of significance 0.05. The research method used is an experiment and the technical analysis used is a two-way ANOVA.

The study concludes that there is an influence between learning strategy training process of problem-based learning and expository learning into the effectiveness of decision making. There is also an impact on group cohesiveness and the efficiency of decision making, and there is influence on mutual interaction between learning strategy training method, expository learning, and group cohesiveness into the effectiveness of decision making.
\end{abstract}

Keywords: Learning strategy training, problem-based learning, expository learning, cohesiveness, decision making.

\section{INTRODUCTION}

The success and failure of high school teachers depends on the effectiveness of a teacher's decisionmaking. Therefore related to the quality of education, management requires the effectiveness of a good teacher decision-making and must have leadership behaviors that can influence the learners to take an active and responsible role to achieve educational goals.

Based on field observations and preliminary survey results on the effectiveness of decision making through questionnaires using a rating scale to 30 high school teachers in Bekasi City, it can be seen that some of the symptoms of poor decision making were made by some teachers.

Observing some of the symptoms about poor decision making done by some teachers, it needs to get attention and need to be further investigated that is how to improve the level of success of systematic actions to solve problems in making decisions. The steps of decision range from the stage of identification and problem formulation, analyzing data and information, development and selection of alternatives, and the implementation of actions, which aim to improve the poor circumstances, in this case, the problem of learning.

Based on the above explanation, the research (experiment) is done to see the problem in more detail by answering the following questions:

1. Is there any effect of decision-making effectiveness between the training group of problem-based learning strategy and the training group of learning expository learning strategy?

2. Is there any influence of decision effectiveness between training group of problem-based learning approach and a team of learning expository learning strategy that has high cohesiveness?

3. Is there any impact of decision-making effectiveness between training group of problem-based learning approach and the team of learning expository learning strategy with low cohesiveness?

4. Is there any interaction of learning strategy training and group cohesiveness to the effectiveness of decision making 


\section{LITERATURE REVIEW}

Some experts explain the theories of decision-making effectiveness. According to Gibson \& Ivancevich (2006), decision-making is a process of tracking and detecting the scope of problematics and the process of recognizing problems against comparative action makers. According to Colquitt, LePine, and Wesson (2009), decision making is the process of presenting and deciding a set of alternatives to solving a problem. According to Chaffe (2000), decision-making is a management approach focused on managerial decision making and how organizational and information processes are used in decision making or the process of choosing among alternative actions to overcome problems. Thus, the focus of decision making is the pattern to analyze the situation by obtaining the information as accurately as possible.

From several theories above, it can be concluded that the effectiveness of decision-making is the level of success of systematic actions to solve problems in making decisions, ranging from the stage of identification and problem formulation; collecting and analyzing data and information; alternative development and selection; and the implementation of actions, whose purpose is to improve the unsatisfactory circumstances. Decision-making indicators are based on decision stages: a. Determination of learning objectives, b. Identifying learning problems c. Development of choice of learning strategy, d. Evaluation of learning options, e. applying learning decisions, f. supervision of application and assessment of learning.

Some experts describe the theories of group cohesiveness. According to Stephen P. Robbins (2013) states: What can you do to encourage group cohesiveness? a. Make the group smaller, b. Support the agreement of group goals, c. Add a time of serenity among team members. d. Improve group status and difficulty in maintaining group membership, e. Stimulate competition with other groups, f. Reward groups rather than individuals, g. Isolate groups physically.

John R. Schermerhorn, James G. Hunt and Ricahrd N. Osborn (2001) states: cohesiveness is the degree to which members are attracted to and motivated to remain a part of a team. Fred Luthans (2011) says that cohesiveness is the extent to which group members are attracted to each other and are motivated to stay in the group. Cohesiveness is the degree to which group members are attracted to each other and are motivated to stay in one group. From the above theories above, what is meant by group cohesiveness is the strong desire of team members to remain part of their group, and the members of the group are interested and motivated each other, accept group goals, and help the work that makes them meet.

Some scholars describe the following training theories. According to Faustino Cardoso Gomes (2001) training is every effort to improve the worker's performance on a particular job that is his responsibility, or a job that has something to do with his work. According to John P. Wilson: (2008) training is planned to modify attitude, knowledge or skill behavior through learning experience to achieve effective performance in an activity or range of activities. Its purpose, in the work situation, is to develop the abilities of the individual and to satisfy the current and future needs of the organization.

From the above theories, it can be concluded that training is a way of teaching knowledge and skills and attitudes so that employees are more skilled and able to carry out their responsibilities better, following the standards and wishes of an organization/company / institution.

Some experts describe the theories of learning strategies. According to Ward, Stepien, in Ngalimun, (2014) Problem-Based Learning (PBL) is a learning model that involves learners to solve a problem through the stages of scientific method so that students can learn knowledge related to the problem and at the same time have the skills to address the problem. Hmelo-Silver, Serafino and Chiccheli in Paul Eggen (2012) suggest that problem-based learning is a set of problem-driven models as a focus for developing problem-solving, material, and self-organizing skills. Based on the opinion of these experts it can be concluded that Problem Based Learning is a learning approach that uses real-world problems as a context for learners to learn about critical thinking and problem-solving skills, and to acquire knowledge and concepts the essential of the learning material.

Roy Killen in Vienna Sanjaya (2006) states that the learning expository (direct instruction) is a direct learning strategy by a teacher to a group of students. Students are not required to find the material. The subject matter as if it had already become. The expository strategy emphasizes the chalk and talk 
process. According to Jacobsen, Eggen, and Kauchak in Rusmono (2014) that expository learning is a teacher-centered learning process, the teacher is the primary source and information given. Based on the opinion of these experts, it can be concluded that expository learning is the delivery of knowledge to learners. Under this condition, students are seen as objects that receive what is given by the teacher and is expected to capture and remember the information provided by the teacher, and then can reveal return what it has through the response given when the teacher asks questions. Teachers play a more active role, more activity than the students. Expository learning steps: a. Preparation, b. Apperception of the precursor, c. Presentation of new materials, d. Recitation.

Based on the literature review the following hypothesis is formulated:

1. There is a positive influence on the group training of problem-based learning strategy and team of learning expository to decision-making effectiveness.

2. There is a positive impact on the group training of problem-based learning strategy and team of learning expository that has the high cohesiveness to the effectiveness of decision making.

3. There is a positive influence on the group training of problem-based learning strategy and organization of learning expository which has a low cohesiveness to the effectiveness of decision making

4. There is interaction of learning strategy training and group cohesiveness to decision-making effectiveness

\section{Data Collection}

This research uses the experimental method because the researcher is looking for a causal relationship by giving special treatment to a group of the teacher which is given the material of learning strategy of Problem Based Learning (PBL) and compared with group of teacher given materials of conventional expository learning. In analyzing the data obtained, the researchers followed the analysis technique: two-way ANOVA with design treatment by level. This research uses the experimental method with factorial design two by 2 .

Table1. Experiment Design

\begin{tabular}{|l|c|c|}
\hline \multirow{2}{*}{ Group Cohesiveness (B) } & \multicolumn{2}{|c|}{ Learning Strategy Training (A) } \\
\cline { 2 - 3 } & Problem Based Learning (A1) & Expository Learning (A2) \\
\hline Low (B1) & A1B1 & A2B1 \\
\hline High (B2) & A1B2 & A2B2 \\
\hline
\end{tabular}

Notes:

- A1B1: The effectiveness of decision making on learning problem based learning strategy training with low group cohesiveness.

- A2B1: The effectiveness of decision making in the practice of learning expository learning approach with low group cohesiveness.

- A1B2: Effectiveness of decision making in the training of problem-based learning strategy with high group cohesiveness.

- A2B2: Effectiveness of decision making on training learning strategy of expository learning with high group cohesiveness.

The sample in this research is two units taken from all teachers in private high school environment of Bekasi city, West Java, Indonesia with an A (excellent) accreditation. Sampling technique uses upper and lower group that is $33.3 \%$ with a high cohesiveness and $33.3 \%$ of the group with the low cohesiveness of each experimental class and control class drawn randomly from teachers throughout the private high schools. Because each sample class is 45 people, 33.3 percent is 15 people, so a sample of 60 teachers is drawn from the entire population. Out of the 60 , teachers are divided into four groups, each 15 teachers.

The research variables consist of the dependent variable $(\mathrm{Y})$ that is decision making effectiveness, while the independent variable treatment is learning strategy training, with the category; A1 = learning-based problem-based learning (PBL) and $\mathrm{A} 2=$ expository problem learning (EPL). The attributed variables $(\mathrm{B})$ are $=$ group cohesiveness, by category; $\mathrm{B} 1=$ high group cohesiveness and $\mathrm{B} 2$ $=$ low group cohesiveness. 


\section{RESUlT AND DISCUSSION}

Hypothesis testing result is shown in the following table.

Table2. Two-Way ANOVA Hypothesis Test

\begin{tabular}{|c|c|c|c|c|c|}
\hline \multicolumn{7}{|c|}{ Tests of Between-Subjects Effects } \\
\hline \multicolumn{7}{|c|}{ Dependent Variable: Effectiveness } \\
\hline Source & $\begin{array}{c}\text { Type III Sum of } \\
\text { Squares }\end{array}$ & df & Mean Square & F & Sig. \\
\hline Corrected Model & $4037.004^{\mathrm{a}}$ & 3 & 1345.668 & 40.458 & .000 \\
\hline Intercept & 149998.000 & 1 & 149998.000 & 4509.739 & .000 \\
\hline Learning Strategy & 2227.479 & 1 & 2227.479 & 66.970 & $\mathbf{. 0 0 0}$ \\
\hline Cohesiveness & 1660.687 & 1 & 1660.687 & 49.929 & $\mathbf{. 0 0 0}$ \\
\hline $\begin{array}{c}\text { Learning Strategy * } \\
\text { Cohesiveness }\end{array}$ & 148.838 & 1 & 148.838 & 4.475 & $\mathbf{. 0 3 9}$ \\
\hline Error & 1862.611 & 56 & 33.261 & & \\
\hline Total & 155897.614 & 60 & & & \\
\hline Corrected Total & 5899.614 & 59 & & & \\
\hline
\end{tabular}

Based on the results of the analysis of data can be interpreted there are significant differences in learning strategy training that is problem-based learning and expository learning to the effectiveness of teachers' decision making. This is marked by the value of sig.value for learning strategy 0.000 $<0.05$. This is also supported by the acquisition of average effectiveness of teacher decision-making scores on 56.09 problem-based learning strategies higher than the efficiency of teacher decision making on learning expository strategy equal to 43.91 .

The results of this study found that the strategy of problem-based learning is better than expository learning because of problem -based learning is a learning approach that encourages learners to know how to work together in groups to seek solutions to problems in the real world. It is in the opinion of Kunandar (2011) that problem-based learning is a learning approach that uses real-world problems as a context for learners to learn about critical thinking and problem-solving skills, and to acquire essential knowledge and concepts from teaching materials.

Based on the results of the analysis of data, it can be interpreted there is a significant influence on the group given the training of problem-based learning and group gave the learning expository in the group with high cohesiveness.

In groups A1B2 and A2B2 sig. Value is $0.000<0$. 05. Teachers who have high cohesiveness given problem-based learning training (PBL) are more useful in decision making than those provided with expository problem learning (EPL) training. It is measured the average effectiveness of decisionmaking for PBL with the high cohesiveness of 62.93 greater than EPL class with the high cohesiveness of 47.59 .

The results show that a teacher who has high cohesiveness will be more diligent, tenacious and enthusiastic in teaching, never give up and happy in facing challenges, accustomed to teaching independently and creatively and always eager to excel. This is in line with the opinions of John R. Schermerhorn, James G. Hunt and Richard N. Osborn that cohesiveness tends to be high when members of homogeneous groups in age, attitude, needs and background (John R. Schermerhorn, James G. Hunt, and Ricahrd N Osborn, 2001).

Based on the results of the analysis of data, it can be interpreted there are significant differences between the group given the training of problem-based learning strategies and units that are provided training of expository learning in the group of low cohesiveness. It can be seen in the panel A1B1 with A2B1 also have a sig. Value 0. $000<0.05$. Teachers given PBL training are more effective in decision making than those given EPL training. This is measured by the average effectiveness of decision-making for PBL with the small compactness of 49.26 higher than the class of expository learning with the low cohesiveness of 40.22 . 
Teachers with a low level of cohesiveness, after being given problem-based learning (PBL) training, in decision making more efficient, this happens because teachers together to help each other member in making, implementing and evaluating a program, so that leads to the level of effectiveness of taking the decision. This is in line with the opinions of Jacobsen, Eggen, and Kauchak that expository learning is a teacher centered learning the process; the teacher is the primary source and information giver (Paul Eggen, 2012).

Based on the results of the analysis of data, it can be interpreted there is a significant influence of interaction of learning strategy training method and group cohesiveness to the effectiveness of teacher decision making. This is per hypothesis test results for the interaction of learning methods, and group cohesiveness obtained sig. Value $0.039<0.05$.

Based on the results of research, it can be argued that the effectiveness of teacher decision making is also determined by the cohesiveness of the group. The cohesiveness of the master group shows the high working group that the members of the group are interested in and motivated each other, accepting group goals, and helping the work that makes them meet. This is in line with the opinions of John R. Schermerhorn, James G. Hunt and Richard N. Osborn (2001) that compactness tends to be high when members of homogeneous groups in age, attitude, needs, and background.

Table3. Tukey Test

\begin{tabular}{|c|c|c|c|c|c|c|}
\hline \multicolumn{7}{|c|}{ Multiple Comparisons } \\
\hline \multicolumn{7}{|c|}{ Dependent Variable: Effectiveness } \\
\hline \multicolumn{7}{|c|}{ Tukey HSD } \\
\hline \multirow{2}{*}{$\begin{array}{l}\text { Groups } \\
\text { (I) }\end{array}$} & \multirow{2}{*}{$\begin{array}{c}\text { Groups } \\
(\mathrm{J})\end{array}$} & \multirow{2}{*}{$\begin{array}{l}\text { Mean Difference } \\
\text { (I-J) }\end{array}$} & \multirow[b]{2}{*}{ Std. Error } & \multirow[b]{2}{*}{ Sig. } & \multicolumn{2}{|c|}{$95 \%$ Confidence Interval } \\
\hline & & & & & Lower Bound & Upper Bound \\
\hline \multirow[t]{3}{*}{1} & 2 & $-13.6720^{*}$ & 2.10589 & .000 & -19.2482 & -8.0958 \\
\hline & 3 & $9.0360^{*}$ & 2.10589 & .000 & 3.4598 & 14.6122 \\
\hline & 4 & 1.6640 & 2.10589 & .859 & -3.9122 & 7.2402 \\
\hline \multirow[t]{3}{*}{2} & 1 & $13.6720^{*}$ & 2.10589 & .000 & 8.0958 & 19.2482 \\
\hline & 3 & $22.7080^{*}$ & 2.10589 & .000 & 17.1318 & 28.2842 \\
\hline & 4 & $15.3360^{*}$ & 2.10589 & .000 & 9.7598 & 20.9122 \\
\hline \multirow[t]{3}{*}{3} & 1 & $-9.0360^{*}$ & 2.10589 & .000 & -14.6122 & -3.4598 \\
\hline & 2 & $-22.7080^{*}$ & 2.10589 & .000 & -28.2842 & -17.1318 \\
\hline & 4 & $-7.3720 *$ & 2.10589 & .005 & -12.9482 & -1.7958 \\
\hline \multirow[t]{3}{*}{4} & 1 & -1.6640 & 2.10589 & .859 & -7.2402 & 3.9122 \\
\hline & 2 & $-15.3360^{*}$ & 2.10589 & .000 & -20.9122 & -9.7598 \\
\hline & 3 & $7.3720^{*}$ & 2.10589 & .005 & 1.7958 & 12.9482 \\
\hline \multicolumn{7}{|c|}{$\begin{array}{c}\text { Based on observed means. } \\
\text { The error term is Mean Square (Error) }=33.261 \text {. }\end{array}$} \\
\hline \multicolumn{7}{|c|}{ *. The mean difference is significant at the .05 level. } \\
\hline
\end{tabular}

Based on further test of turkey test it is conclude:

A) In groups 1 and 2 (A1B1 and A1 B2) there found the different learning strategy of PBL (Problem Based Learning) with high and low cohesiveness. It shows that the mean difference of $(-13,672)$ said the difference between group 1 and 2 averaged of 13. 672. This value is quite significant and is proved by a sig. value of $0.000<0.05$, or in other words it can be interpreted that there is a different influence between groups 1 and 2. In the Problem Based Learning (PBL) learning strategy, teachers who have high cohesiveness are more active in making decisions than teachers who have low cohesiveness.

B) In groups 1 and 3 (A1B1 and A2 B1) there found the differences in learning strategies of PBL (Problem Based Learning) with low cohesiveness and also expository learning with low cohesiveness. It can be seen that the Mean Difference of (9.0360) meaning the difference between group 1 and 3 averaged of 9.0360. This value is quite significant and proved by the value of sig $0.000<0.05$ or in other words; it can be interpreted there is a difference of influence between groups 1 and 3. Teachers who have low cohesiveness in PBL learning is more effective in making decisions than teachers who have low cohesiveness in the expository learning class.

C) In groups 2 and 4 (A1B2 and A2B2) are found the differences in PBL (Problem Based Learning) learning strategies with high cohesiveness and expository learning with high cohesiveness. It can 
be seen that Mean Difference of (15.3360) meaning the difference between group averaged 2 and four are 15.3360. This value is quite significant and proved by the value of sig $0.000<0.05$, or in other words, and it can be interpreted there are differences in influence between groups 2 and 4 . Teachers who have high cohesiveness in PBL are more active in making decisions compared to teachers who have strong cohesiveness in the expository learning class.

D) In groups 3 and 4 (A2B1 and A2B2) there is a different learning strategy of high cohesiveness expository learning and low cohesiveness expository learning. It can be seen that Mean Difference of (-7.3720) indicating the difference between group 3 and four averaged of 7.3720. This value is quite significant and proved by the value of sig $0.005<0.05$, or in other words; it can be interpreted there are differences in influence between groups 3 and 4 . Teachers who have high cohesiveness in expository learning is more effective in making decisions than teachers who have low cohesiveness in the expository learning class.

\section{CONCLUSiON}

Based on the results of data analysis and hypothesis testing in this study, it can be concluded as follows:

1. There is influence of decision-making effectiveness between training group of problem-based learning strategy and expository learning strategy.

2. There is the importance of decision effectiveness between training group of problem-based learning strategy and organization of expository learning which has high cohesiveness.

3. There is the importance of decision effectiveness between training group of problem-based learning strategy and structure of expository learning which has low cohesiveness.

4. There is an interaction between learning strategy training and group cohesiveness to decisionmaking effectiveness.

\section{REFERENCES}

[1] Colquitt, J.A, LePine, and Wesson. Organization Behaviour; Improving Performance, Commitment in the Workplace, Second Edition. New York: Mc Grow Hill.2009.

[2] Gibson James M. Organizations: Behavior, Structure, Processes, International Edition, New York: Mc Graw-Hill Companies, 2006.

[3] John R. Schermerhorn, James G. Hunt, and Richard N. Osborn. Managing Organizational Behavior: a global perspectives. Sydney: John Wiley \& Sons Australia, 2001.

[4] Kunandar.Guru Profesional Implementasi Kurikulum Tingkat Satuan Pendidikan (KTSP) dan Sukses dalam Sertifikasi Guru. Jakarta: PT RajaGrafindo Persada, cetakan ketujuh, 2011

[5] Luthans, Fred. Organizational behaviour: An Evidence-Based Approach, Mc Graw-Hill Irwin Companies, 2011

[6] Ngalimun. Strategi dan Model Pembelajaran.Yogyakarta:Aswaja Pressindo,Cetakan ketiga, 2014.

[7] Paul Eggen. Strategi dan Model Pembelajaran. Jakarta:PT. Indeks,edisi ke enam,2012.

[8] Robbins, Stephen P. Organizational Behavior, Upper Saddle River, New Jersey Prentice- Hall Inc.2013.

[9] Rusmono,Strategi Pembelajaran dengan Problem Based Learning Itu Perlu .Jakarta: Penerbit Ghalia Indonesia,Cetakan kedua ,2014.

[10] Wina Sanjaya. Strategi Pembelajaran Berorientasi Standar Proses Pendidikan.(Jakarta: Kencana,Cetakan ke $-1,2006$

Citation: Harti, Supriatin et al. "The Effect of Learning Strategy Training and Group Cohesiveness on Effectiveness of Decision Making." International Journal of Managerial Studies and Research (IJMSR), vol 5, no. 9, 2017, pp. 17-22. doi:http://dx.doi.org/10.20431/2349-0349.0509003.

Copyright: (ㅇ 2017 Authors. This is an open-access article distributed under the terms of the Creative Commons Attribution License, which permits unrestricted use, distribution, and reproduction in any medium, provided the original author and source are credited. 